\title{
The Equity and Efficiency of Microfinance
}

Mahazarin Kanga, Juhi Bansal, Siddharth Verma \& Ishani Bandaranayake

Banks are for people with money rather than for people without money. However, microfinance is banking for the unbankables. It brings credit, loan, savings and other essential financial services within the reach of millions of people who are too poor to be served by regular banks, i.e. almost $60-90 \%$ of the global population. It is one of the most intriguing features of financial economics today.

In the aftermath of the 2006 Nobel Peace Prize being awarded to the Bangladeshi, Mohammed Yunus, who is a champion of the cause for microcredit, the common presumption has been that microfinance creates undeniable social benefits such as poverty alleviation and more equal social opportunities. Indeed, this is true to a large extent; however, less acknowledged are the problems that lurk behind this facade of 'social service'.

Donning the caps of economists, this paper discusses the economic rationality of microfinance as an effective tool for achieving poverty alleviation. We ask the question on whether the theoretical objective of microfinance for 'helping the poor' is sullied in practice by rent seeking, profit seeking and corruption. We assess the fundamental economic model for the basis on which Microfinance Institutions (MFIs) provide loans to the poor and as whether the poor people eventually benefited from this financial innovation. 


\section{Some Background}

Imagine what would happen if the universal banking structure would crumble and all the financial organizations stopped working. Banks would shut down, ATMs would not be operating, and credit and debit cards would no longer be accepted. Millions of families would not be able to provide food on their dinner table. Well, this is exactly the problem faced by more than $60 \%$ of the global population - a nightmare they endure very day.

Therefore, the need for microfinance is quite startling. One of the primary lessons in economics is that of 'diminishing marginal returns' which would suggest that enterprises with little capital (or poor entrepreneurs) earn higher returns on their investment because they utilize less capital. While the net output of such enterprises may not be high, on each additional unit of output, their marginal returns will be greater. Similarly, organizations with greater capital at their disposal (richer entrepreneurs) use more capital and hence produce a higher net output, but their marginal returns from each additional unit is smaller too.

According to this law, poor entrepreneurs will earn more on each additional unit and hence they will be able to pay higher interest as compared to a richer entrepreneur. This would suggest that the willingness to finance smaller enterprises and poorer entrepreneurs should be high. However, reality does not follow this law, primarily due to the risk associated to lending to unproven entrepreneurs and smaller enterprises. As a result, since generations, poverty has always reproduced poverty exacerbating income inequality in the process.

For mainstream financial institutions operating in the real world, the market of poor entrepreneurs is characterized by high operating costs and lack of financial information. Banks and many other commercial organizations as well as NGOs face huge transaction costs because the cost for handling a small transaction is very expensive simply because they cannot take advantage of economies of scale and scope in this market. Consequently, a majority of poor consumers are entirely avoided by the banks because they are seen as 
risky and expensive, in other words, not trustworthy for repaying a loan. And this is where the need for microfinance was born and hence is seen as a method to break through this vicious circle of poverty. Seen as such, microfinance is not the first step towards poverty alleviation, but it is the most successful tool by far. (Armendariz and Morduch, 2007)

\section{Microfinance in the Real World - The Case of India}

To see how microfinance operates in reality, consider, for example, the usual delivery channels of microfinance in India. They include:

- Grameen Banks

- Self Help Groups (SHGs) including some NGOs

- Micro-financial Institutions (MFIs) such as banks

- SHG Bank Linkage Programme (SHG - BLP)

Since microfinance was initially started as "banking for the poor", credit checks and collateral security is still not the basis for providing loans to the poor for most models of microfinance.

The most successful model in India in terms of scale and outreach is the SHG Bank Linkage Programme with other models lagging far behind. In 2004, around 800,000 SHGs were linked to the banks and together they have reached around 2 million households. Despite these huge numbers, their coverage covers barely $5 \%$ of all Indian poor rural households (Basu and Srivastava, 2004).

The different channels for microfinance in India seem to exhibit some interesting advantages compared to one another. For instance, informal microfinance institutions (SHGs) formed mutually among borrowers are closer to the grass root level and more capable at dealing with the credit assessment of the urban poor. They are thereby able to lower the transaction costs of loan processing. On the other hand, the formal financial sector has a wider resource base and the related ability to expediently mobilize the funds 
required, thereby reducing the cost capital for SHGs. Further, both formal and informal sectors reduce overall transaction costs and increase their expected profit because of lower default rates on lending portfolios (less than 1\% compared to banks 11 to 12\%) (Tiwari and Fahad n.d). As for the borrowers, loans can be readily available at SHGs at lower rates because of the low cost of processing and easy access to finance through bank linkages.

This SHG model operates by forming a group to save capital, which is then deposited in an account at a bank. The group then applies for a loan by offering their savings and group guarantee as a collateral. Normally banks provide loans amounting to four times the accumulated savings which can be increased further on the basis of the group's track record on the previous loans. Borrowed and saved money are then circulated through lending within the group with usual monthly repayments. Any single default on part of the entire group has the consequence of the bank stopping further loan instalments, putting a stop on the flow of capital to the group which can lead to a loss in their business activities. This disciplinary mechanism results in loan repayments being around $98 \%$ in these cases. (Basu and Srivastava, 2004).

Microcredit also provides the poor with an opportunity to have some consumer surplus which occurs when the cost of the loans they receive is lower than their reservation price for entering into entrepreneurship. Through entrepreneurship the rise in income, standard of living, security, etc is worth more than the interest rate that they pay on the loan borrowed. There is also producer surplus as the expectancy of loan repayment is higher than in the normal case.

Now to further understand the in-depth coverage of microfinance let us look at its market model.

\section{A Market Analysis for Microfinance}

The kind of market in which the MFIs operate can be understood as being monopolistically competitive wherein there are number of buyers and sellers, there is free entry and exit 
and the product sold is differentiated (viz. different maturity periods, terms, interest rates, etc.).

We shall assume that the demand curve represents the price a borrower is willing to pay to take a loan and the supply curve represents the number of loans offered by MFIs.

The existing market conditions in developing countries indicate that the demand for micro loans outstrips its supply. Therefore, at prices for such a loan that would reflect the purported benefits of microfinance most accurately, there is excess demand, whereas at the prevailing equilibrium price the benefits are arguably much more muted. In competitive market conditions, when there is excess of demand over supply in the market, new suppliers would enter the market so as to benefit from the potential to earn short term economic profit, shifting the supply curve towards right and adjusting the equilibrium price downward. Restricting this scenario are the government regulations preventing new entry by imposing stringent capital adequacy and complex supervisory and reporting requirements and further non supportive infrastructure facilities.

Unfortunately microfinance in India still has a lot to cover and many to reach. The particular models offered at present still result in a lot of spatial inequality in terms of the coverage of clients - microfinance remains more accessible in urban areas whereas it should ideally reach the most vulnerable clients in remote areas. Thus there is still glaring inequalities to access that requires addressing.

\section{Externalities}

Despite its theoretical positive impacts, the real world progress of microfinance is still very restricted owing to a number of reasons. First, microfinance is intrinsically a very convoluted service to comprehend and hence its uptake is very slow. Reduced uptake levels increase the transaction costs making microfinance costlier.

There is usually an inverse correlation (trade off) between the size of a portfolio and the break-even premium that plagues microfinance acutely. This is because if MFIs were to 
raise their premiums, it would limit accessibility to the poor. Conversely, if the premiums are kept low and participation is encouraged it could potentially make microfinance financially unviable. The latter seems to be a more suitable approach but the problem is that any program has to survive until it reaches its break-even point. The ability of microfinance in assuaging poverty in the longer term without becoming financially unviable in the short term is essentially the crux of the problem.

Another problem is the bundling of microfinance programs which refers to different microfinance programs operating collectively. For e.g. the "group lending" model by Grameen Bank in Bangladesh, wherein if one individual fails to repay, the others in the group are held responsible. However, doing this may lead to collusion between the microfinance service providers which may increase their market power and give rise to competition concerns. (Islam, 2009)

\section{Concluding Remarks}

Microfinance has generated contradictory responses and divisive views. On the one hand are the people who think that microfinance is panacea and can extricate billions of people out of poverty. On the other hand there are critics who discount the real world benefits of microfinance as exaggerated.

We would like to conclude in the middle ground in that microfinance does seem to have a significant potential for poverty reduction, provided it can be put into practice in a manner that addresses the problems of asymmetric access and market participation.

Regardless of its criticisms, if implemented in its authentic sense, the following saying would ring true:

"Give a man a fish; he will eat for a day. Give a woman microcredit, she, her husband, her children and her extended family will eat for a lifetime." Bono 


\section{References}

- Armendariz, B and Morduch, J (2007) The Economics of Microfinance, Massachusetts Institute of Technology Press

- Basu, P and Srivastava, P (2004) “Scaling-up Access to Finance for India's Rural Poor”, World Bank Policy Research Working Paper

- Islam, N (2009) "Can Microfinance reduce economic insecurity and poverty? By How much and How?" DESA Working Paper no. 82, Economic and Social Affairs, retrieved 20 June 2010, <http://www.un.org/esa/desa/papers/2009/wp82_2009.pdf>

- Tiwari, P \& Fahad, S.M n.d, “Concept Paper: Microfinance Institutions in India”, Housing Development Finance Corporation, retrieved 15 May 2010, http://www.gdrc.org/icm/conceptpaper-india.html 